DOI: https://doi.org/10.24127/ajpm.v9i2.2758

\title{
HUBUNGAN KEMANDIRIAN BELAJAR TERHADAP KEMAMPUAN BERPIKIR KRITIS MELALUI PENGGUNAAN SOFTWARE GEOGEBRA
}

\author{
Ali Asmar ${ }^{1}$, Hafizah Delyana ${ }^{2}$ \\ ${ }^{1}$ Pendidikan Matematika, Universitas Negeri Padang, Padang, Indonesia \\ ${ }^{2}$ Pendidikan Matematika, STKIP PGRI Sumatera Barat, Padang, Indonesia \\ E-mail: $\quad$ aliasmar.sumbar@gmail.com ${ }^{1)}$ \\ hafizahdelyana@gmail.com $^{2)}$
}

Received 15 April 2020; Received in revised form 11 June 2020; Accepted 20 June 2020

\begin{abstract}
Abstrak
Penelitian ini bertujuan untuk mengetahui tentang hubungan antara kemandirian belajar dengan kemampuan berpikir kritis mahasiswa melalui penggunaan software Geogebra. Penelitian ini merupakan penelitian eksperimen. Jumlah sampel pada penelitian ini adalah 40 orang mahasiswa Program Studi Pendidikan Matematika Universitas Negeri Padang. Instrumen yang digunakan adalah tes dan angket. Tes yang digunakan berbentuk essay dan memuat indikator kemampuan berpikir kritis, sedangkan angket kemandirian terdiri atas 28 butir pernyataan. Metode penelitian yang digunakan ialah metode korelasi dengan pendekatan kuantitatif. Teknik analisis data menggunakan uji korelasi untuk mengetahui hubungan antara berpikir kritis dengan kemandirian belajar mahasiswa. Hasil penelitian ini menunjukkan bahwa ada hubungan antara kemandirian belajar terhadap kemampuan berpikir kritis mahasiswa melalui penggunaan software Geogebra pada pokok bahasan Geometri khususnya pada materi jarak bidang ke bidang. Hasil tersebut dilihat bahwa nilai korelasi Pearson sebesar 0,412 menunjukkan kekuatan hubungan antara kemandirian belajar terhadap kemampuan berpikir kritis mahasiswa. Di samping itu, diperoleh nilai Sig. sebesar 0,014 lebih kecil dari 0,05. Sehingga dapat disimpulkan bahwa kekuatan hubungan antara kemandirian belajar terhadap kemampuan berpikir kritis mahasiswa signifikan.
\end{abstract}

Kata kunci: Kemandirian belajar; berpikir kritis; software geogebra.

\begin{abstract}
This study aims to find out about the relationship between learning independence with students' critical thinking skills through the use of Geogebra software. This research is an experimental research. The number of samples in this study were 40 students of the Mathematics Education Study Program, Padang State University. The instruments used were tests and questionnaires. The test used was in the form of essays and contained indicators of critical thinking skills, while the questionnaire for independence consisted of 28 statements. The research method used is the correlation method with a quantitative approach. Data analysis techniques used correlation tests to determine the relationship between critical thinking and student learning independence. The results of this study indicate that there is a relationship between learning independence of students' critical thinking skills through the use of Geogebra software on the subject of Geometry, especially in the material field to field distance. These results are seen that the Pearson correlation value of 0.412 indicates the strength of the relationship between learning independence and critical thinking abilities of students. In addition, the value of Sig. amounted to 0.014 smaller than 0.05. So it can be concluded that the strength of the relationship between learning independence and critical thinking ability of students is significant.
\end{abstract}

Keywords: Critical thinking; geogebra software; learning independence.

\section{PENDAHULUAN}

Teknologi memiliki peranan yang penting pada berbagai bidang kehidupan tidak terkecuali dalam bidang pendidikan, khususnya dalam pembelajaran geometri. Pemanfaatan ICT (Information and Communication Technology) dapat membantu 
DOI: https://doi.org/10.24127/ajpm.v9i2.2758

mahasiswa dalam pembelajaran matematika (Rohendi, 2012). Berdasarkan hasil survey peneliti (tanggal 20 Oktober 2019) berupa pemberian tes diagnosis kepada mahasiswa menunjukkan bahwa $74,28 \%$ dari jumlah mahasiswa kesulitan menggambarkan kurva dari sebuah persamaan kutub Kurangnya pemahaman konsep dan berpikir kritis siswa tersebut dapat dilihat dari contoh soal dalam mensketsakan persamaan kutub dan menghitung luas daerah yang dibatasi oleh persamaan kutub yang diberikan.

Mencermati masalah di atas tentunya media pembelajaran sangat berperan penting, apalagi materi tersebut merupakan ilmu matematika yang menuntut mahasiswa dapat mengaplikasikannya dalam bentuk gambar. Sehingga diperlukan sebuah alat bantu berupa software untuk memudahkan siswa memahami konsep khususnya geometri. Dengan memanfaatkan software, proses penerimaan mahasiswa terhadap materi akan lebih berkesan secara mendalam sehingga membentuk pengertian dengan baik dan sempurna. Salah satu media pembelajaran yang dapat dimanfaatkan dalam pembelajaran matematika, yaitu Geogebra.

Hal ini sejalan dengan (Saputra, 2019) yang menyatakan bahwa aplikasi Geogebra memiliki banyak kemungkinan membantu mahasiswa untuk dapat memvisualisasikan proses matematika yang berkualitas, serta mampu menunjukkan kemandirian belajar matematika. Di samping itu, penelitian yang dilakukan (Van-Oers, 2010) juga ditemukan bahwa kemampuan berfikir matematis mahasiswa dapat muncul dengan sendirinya dengan permainan yang dihubungkan dengan pengalamannya.
Permainan yang dimaksud adalah keterlibatan media Geogebra yang membuat mahasiswa seperti bermain dengan komputernya.

Aplikasi ini dikembangkan oleh Markus Hohenwarter pada tahun 2001. Menurutnya, geogebra merupakan program komputer gratis yang dirancang untuk menggabungkan geometri, kalkulus, aljabar dalam satu lingkunan yang dinamis. Beberapa penelitian menunjukkan bahwa geogebra dapat mendorong proses eksperimen siswa. Dengan pemanfaatan media ini mahasiswa mendapatkan pengalaman, dan mahasiswa mandiri mengkonstruk konsep secara umum. Hal ini sejalan dengan (Mardiana, S., \& Qohar, 2017) yang menyatakan bahwa media komputer menunjang kegiatan belajar mahasiswa serta memotivasi mahasiswa dalam belajar.

Alasan software Geogebra dipilih adalah karena software tersebut memiliki menu yang lengkap sehingga memudahkan mahasiswa memvisualisasikan konsep-konsep pada materi dimensi tiga. Selain itu penelitian ini diharapkan memiliki hasil tambah yaitu meningkatnya minat mahasiswa pada pembelajaran matakuliah geometri analitik ruang karena melibatkan teknologi komputer. Hal ini didukung oleh (Supriadi, 2015) yang menyatakan bahwa hasil belajar siswa setelah mendapat pembelajaran dengan menggunakan software interaktif seperti Geogebra meningkat jauh lebih tinggi dibandingkan sebelum menggunakan media ajar software Geogebra.

Disamping itu, terdapat tiga domain dalam taksonomi Bloom yang dibuat untuk tujuan pendidikan, yaitu domain kognitif, domain afektif, dan domain psikomotorik (Cullinane, 2009). Salah satu domain afektif yang 
penting dimiliki mahasiswa adalah kemandirian belajar. Hal ini sejalan dengan (Kurniati, 2018) yang menyatakan bahwa dengan GeoGebra sangat memungkinkan untuk membuat mahasiswa mempraktikkan kemampuan spasial mereka secara mandiri yang akan menumbuhkan pembelajaran mandiri mereka.

Disamping itu, menurut (Saputra, 2019) salah satu cara untuk mendorong mahasiswa untuk meningkatkan kemandirian belajar adalah dengan memberi mahasiswa kesempatan untuk menyelesaikan tugas kelompok yang berkualitas dan mendorong mereka untuk belajar satu sama lain dan mengembangkan ide mereka sendiri. Salah satunya dengan memanfaatkan teknologi computer.

Proses proaktif yang digunakan mahasiswa dalam memperoleh keterampilan akademik, seperti menetapkan tujuan, memilih dan menerapkan strategi, dan memantau efektivitasnya sendiri merupakan bentuk dari kemandirian belajar (Eliserio, 2012). Sehingga, dapat disimpulkan bahwa, kemandirian belajar adalah suatu kondisi seorang individu memiliki inisitatif untuk belajar, menetapkan tujuan belajar dan strategi belajar, dan mengevaluasi atau refleksi diri dalam kegiatan belajarnya.

Kemandirian belajar seorang individu diduga memiliki kaitan yang erat dengan kemampuan berpikir kritis. Hal ini disebabkan karena kemandirian belajar merupakan suatu usaha yang dilakukan untuk melakukan aktivitas belajar dengan cara mandiri atas dasar motivasinya sendiri untuk menguasai suatu materi tertentu sehingga bisa dipakai untuk memecahkan masalah (Egok, 2016). Sehingga, dapat dipahami bahwa yang dimaksud dengan berpikir kritis adalah kemampuan untuk berpikir secara logis, reflektif, dan produktif yang diaplikasikan dalam menilai situasi untuk membuat pertimbangan dan keputusan yang baik.

Menurut (Hendryawan et al., 2017) kemampuan berpikir kritis matematika adalah salah satu keterampilan berpikir tingkat tinggi yang harus dimiliki siswa. Kemampuan berpikir kritis matematika menjadi penting dalam matematika.Hal ini sejalan dengan pendapat (Batubara, 2019) yang menyatakan bahwa dengan berpikir kritis peserta didik juga tidak sekedar mengetahui atau mengingat sejumlah konsep yang dipelajari, tetapi mampu mengungkapan kembali dalam bentuk lain yang mudah dimengerti, memberikan interprestasi data dan mampu mengaplikasikan konsep yang sesuai dengan struktur kognitif yang dimilikinya. Hal tersebut juga senada dengan (Dunne, 2015) yang menyatakan bahwa Siswa yang memiliki kemampuan berpikir kritis dapat berpikir rasional dan mampu untuk mengaplikasikan pemikiran kritis mereka ke dalam permasalahan matematis.

Pembelajaran geometri diharapkan memberikan suatu sikap dan kebiasaan sistematik bagi mahasiswa untuk bisa memberikan gambaran tentang hubungan-hubungan di antara bangun-bangun geometri serta penggolongan-penggolongan di antara bangun-bangun tersebut. Dalam belajar geometri diharapkan mahasiswa dapat memvisualisasikan, menggambarkan, memperbandingkan bangun-bangun geometri dalam berbagai posisi, dan menghitung jarak dari titik ke bidang,serta jarak dari bidang ke bidang.

Berdasarkan permasalahan yang diuraikan di atas maka dibutuhkan 
sebuah model pembelajaran berbasis software komputer. Penggunaan software dalam pembelajaran Geometri sangat berdampak baik pada pembelajaran matematika terutama dalam meningkatkan kemandirian belajar dan kemampuan berpikir kritis mahasiswa. Penelitian ini bertujuan melihat hubungan kemandirian belajar siswa dengan kemampuan berpikir kritis mahasiswa dengan menggunakan software geogebra.

\section{METODE PENELITIAN}

Penelitian ini merupakan penelitian eksperimen yang menggunakan pendekatan kuantitatif, dengan metode survei dan teknik korelasional yang menggambarkan tentang variabel-variabel yang diteliti, serta menyelidiki hubungan antar variabel. Penelitian dilakukan untuk memperoleh pembuktian tentang hubungan antara kemandirian belajar $(X)$ mahasiswa terhadap kemampuan berpikir kritis matematis $(Y)$.

Teknik pengambilan sampel menggunakan Purporsive sampling. Sampel yang dipilih adalah satu kelas karena berdasarkan hasil observasi awal dan wawancara dengan dosen pengampu mata kuliah diketahui bahwa kemampuan berpikir kritis mahasiswa masih rendah. Sampel pada penelitian ini adalah 40 orang mahasiswa dari Program Studi Pendidikan Matematika Universitas Negeri Padang.

Instrumen yang digunakan adalah tes dan angket. Tes yang digunakan berbentuk essay dan memuat indikator kemampuan berpikir kritis, indikator yang digunakan pada penelitian ini disajikan pada Tabel 1. Sedangkan angket kemandirian terdiri atas 28 butir pernyataan yang memuat 9 indikator kemandirian belajar. Indikator yang digunakan pada penelitian ini adalah sebagai berikut; 1) inisiatif belajar, 2) mendiagnosa kebutuhan belajar, 3) menetapkan target dan tujuan belajar, 4) memonitor, mengatur dan mengontrol kemajuan belajar, 5) memandang kesulitan sebagai tantangan, 6) memanfaatkan dan mencari sumber yang relevan, 7) memilih dan menerapkan strategi belajar, 8) mengevaluasi proses dan hasil belajar, dan 9) memiliki self efficacy.

Tabel 1. Indikator kemampuan kritis yang ditinjau.

\begin{tabular}{|c|c|c|}
\hline & Kelompok & Indikator \\
\hline 1 & $\begin{array}{l}\text { Memberikan } \\
\text { penjelasan } \\
\text { sederhana }\end{array}$ & $\begin{array}{l}\text { Menganalisis } \\
\text { argumen. } \\
\text { Bertanya dan } \\
\text { menjawab } \\
\text { pertanyaan. }\end{array}$ \\
\hline 2 & Menyimpulkan & $\begin{array}{l}\text { Menginduksi dan } \\
\text { mempertimbangkan } \\
\text { hasil induksi. } \\
\text { Membuat dan } \\
\text { menentukan hasil } \\
\text { pertimbangan. }\end{array}$ \\
\hline 3 & $\begin{array}{l}\text { Mengatur } \\
\text { strategi dan } \\
\text { taktik }\end{array}$ & $\begin{array}{l}\text { Menentukan suatu } \\
\text { tindakan. }\end{array}$ \\
\hline
\end{tabular}

Teknik análisis data yang digunakan adalah Analisis Korelasi untuk mengetahui seberapa erat hubungan antara variabel independen dengan variabel dependen. Langkah pertama adalah menganalisis skor angket kemandirian belajar yang dilakukan dengan menentukan jumlah skor yang diperoleh masing-masing mahasiswa terlebih dahulu. Persentase skor kemandirian belajar dapat dihitung dengan rumus berikut:

$$
\text { skor }(s)=\frac{\text { jumlah skor yang diperoleh }}{\text { jumlah skor maksimum }} \times 100 \%
$$


DOI: https://doi.org/10.24127/ajpm.v9i2.2758

Langkah kedua adalah menganalisis data tes yang dilakukan untuk memperoleh informasi tentang kemampuan berpikir kritis mahasiswa pada kelas eksperimen. Tes dinilai menggunakan rubrik kemampuan berpikir kritis menggunakan indikator kemampuan berpikir kritis yang telah ditentukan. Setiap urutan jawaban mahasiswa dinilai dengan seksama menggunakan rubrik analitik.

Selanjutnya teknik analisis data untuk melihat hubungan kemandirian belajar terhadap kemampuan berpikir kritis mahasiswa menggunakan analisis regresi linear sederhana dengan model sebagai berikut:

$$
\begin{aligned}
Y & =a+b X \\
a & =\frac{\sum X^{2} \sum Y-\sum X \sum X Y}{n \sum X^{2}-\left(\sum X\right)^{2}} \\
b & =\frac{n \sum X Y-\sum X \sum Y}{n \sum X^{2}-\left(\sum X\right)^{2}}
\end{aligned}
$$

Keterangan:

$Y \quad=$ kemampuan berpikir kritis

$a=\operatorname{harga} Y$ bila $X=0$ (harga konstan)

$b=$ angka arah atau koefisien regresi, yang menunjukan angka peningkatan atau penurunan variabel dependen yang didasarkan pada variabel independen.

$X \quad=$ skor angket kemandirian.

\section{HASIL DAN PEMBAHASAN}

Kemandirian mahasiswa dalam proses perkuliahan dapat dilihat dari angket kemandirian yang dibagikan pada kelas eksperimen dengan jumlah responden 40 mahasiswaIndikator kemandirian belajar dalam penelitian ini adalah: (1) insiatif dan motivasi belajar instrinsik; (2) kebiasaan mendiagnosa kebutuhan belajar; (3) menetapkan tujuan/target belajar; (4) memonitor, mengatur, dan mengontrol belajar; (5) memandang kesulitan sebagai tantangan; (6) memanfaatkan dan mencari sumber yang relevan; (7) memilih, menerapkan strategi belajar; (8) mengevaluasi proses dan hasil belajar; dan (9) Self efficacy/ konsep diri/ kemampuan diri.

Tingkat kemandirian belajar mahasiswa dapat dilihat dari persentase indikator yang disajikan pada Tabel 2 .

\begin{tabular}{|c|c|c|c|}
\hline & $\begin{array}{c}\text { Indikator } \\
\text { Kemandirian } \\
\text { Belajar }\end{array}$ & $\begin{array}{c}\text { Skor } \\
(\%)\end{array}$ & Kriteria \\
\hline 1 & $\begin{array}{lr}\text { Insiatif } & \text { dan } \\
\text { motivasi } & \text { belajar } \\
\text { instrinsik } & \end{array}$ & 74,38 & Kuat \\
\hline 2 & $\begin{array}{l}\text { Kebiasaan } \\
\text { mendiagnosa } \\
\text { kebutuhan belajar }\end{array}$ & 63,33 & Kuat \\
\hline 3 & $\begin{array}{l}\text { Menetapkan } \\
\text { tujuan/target } \\
\text { belajar }\end{array}$ & 78,13 & $\begin{array}{c}\text { Sangat } \\
\text { Kuat }\end{array}$ \\
\hline 4 & $\begin{array}{l}\text { Memonitor, } \\
\text { mengatur, dan } \\
\text { mengontrol belajar }\end{array}$ & 71,25 & Kuat \\
\hline 5 & $\begin{array}{l}\text { Memandang } \\
\text { kesulitan sebagai } \\
\text { tantangan }\end{array}$ & 69,17 & Kuat \\
\hline 6 & $\begin{array}{l}\text { Memanfaatkan dan } \\
\text { mencari sumber } \\
\text { yang relevan }\end{array}$ & 72,19 & Kuat \\
\hline 7 & $\begin{array}{l}\text { Memilih, } \\
\text { menerapkan } \\
\text { strategi belajar }\end{array}$ & 74,69 & Kuat \\
\hline 8 & $\begin{array}{l}\text { Mengevaluasi } \\
\text { proses dan hasil } \\
\text { belajar }\end{array}$ & 77,08 & $\begin{array}{c}\text { Sangat } \\
\text { Kuat }\end{array}$ \\
\hline 9 & $\begin{array}{lr}\text { Self } & \text { efficacy/ } \\
\text { konsep } & \text { diri/ } \\
\text { kemampuan diri. }\end{array}$ & 72,5 & Kuat \\
\hline
\end{tabular}

Tabel 2. Persentase perindikator kemandirian belajar.

Berdasarkan Tabel 2 terlihat bahwa persentase 7 indikator kemandirian belajar mahasiswa berada pada interval $50 \%$ - 75\%, sehingga berada pada kategori kuat. Sedangkan 2 indikator yang lainnya, yaitu: 
menetapkan tujuan/target belajar dan mengevaluasi proses dan hasil belajar berada pada kategori sangat kuat. Hasil persentase kemandirian yang diperoleh diperkuat oleh Hal ini juga diperkuat oleh (Sumarmo et al., 2012) yang mengatakan bahwa satu sub-faktor penting dari keadaan individu yang mempengaruhi belajar seseorang adalah kemandirian belajar.

Pelaksanaan tes dilakukan pada kelas eksperimen yang diikuti oleh 40 orang mahasiswa. Selanjutnya data tes akhir dianalisis untuk mengetahui nilai kemampuan berpikir kritis mahasiswa. Berdasarkan perhitungan didapat nilai rata-rata $(\bar{x})$, skor tertinggi $\left(x_{\max }\right)$, skor terendah $\left(x_{\min }\right)$ tes pada kelas eksperimen, dapat dilihat pada Tabel 3.

Tabel 3. Analisis kemampuan berpikir kritis.

\begin{tabular}{ccccc}
\hline $\begin{array}{c}\text { Jumlah } \\
\text { Siswa }\end{array}$ & $\overline{\boldsymbol{x}}$ & $\boldsymbol{x}_{\max }$ & $\boldsymbol{x}_{\min }$ & s \\
\hline 40 & 88,18 & 96,36 & 74,55 & 5,99 \\
\hline
\end{tabular}

Pada Tabel 3 dapat dilihat bahwa nilai tes mahasiswa diperoleh rata-rata 88,18 dengan nilai tes akhir tertinggi adalah 96,36 dan nilai terendahnya dalah 74,55.

Pada soal nomor 1, mahasiswa diminta untuk menghitung jarak antara dua bidang sejajar. Dalam menjawab soal tersebut mahasiswa sudah mampu menjelaskan secara sederhana dengan menganalisis argument dan menjawab dengan baik. Mahasiswa juga sudah menyimpulkan secara benar rumus yang akan dipakai dengan mengemukakan beberapa pertimbangan. Dalam menyelesaikan soal, mahasiswa sudah benar dalam memilih strategi yang tepat dan menentukan suatu tindakan yang tepat dalam menemukan jawaban yang benar. Sehingga, dapat disimpulkan kemampuan bepikir kritis mahasiswa tersebut sudah baik

Berdasarkan data yang diperoleh dari skor angket dan tes akhir yang telah dilakukan, analisis yang dilakukan menggunakan analisis regresi linear sederhana, besarnya nilai korelasi dapat dilihat pada Tabel 4.

Tabel 4. Hasil analisis regresi linier sederhana.

\begin{tabular}{lcccc}
\hline $\begin{array}{l}\text { Mo } \\
\text { del }\end{array}$ & R & $\mathbf{R}^{2}$ & $\begin{array}{c}\text { Adjusted } \\
\mathbf{R}^{2}\end{array}$ & $\begin{array}{c}\text { Std. Error } \\
\text { of the } \\
\text { Estimate }\end{array}$ \\
\hline $\mathbf{1}$ & 0,412 & 0,147 & 0,125 & 5,60665 \\
\hline
\end{tabular}

Tabel 4 menunjukkan nilai koefisien korelasi sebesar 0,412. Hal ini dapat dikatakan hubungan kedua variabel cukup kuat. Hal ini berdasarkan pernyataan (Nduru et al., 2014) yang menunjukkan bahwa nilai $R$ yang berada pada interval 0,400-0,599 berada pada kategori cukup. Selain itu juga dapat dilihat dari nilai $R$ square nya sebesar 12,5 persen, dapat dikatakan variabel kemandirian hanya memiliki pengaruh kontribusi sebesar 12,5 persen terhadap kemampuan kritis, dan 87,5 persen lainnya dipengaruhi oleh faktorfaktor lain diluar kemandirian.

Kemandirian belajar siswa adalah keadaan dimana siswa memiliki keinginan untuk bersaing demi kebaikan dirinya, sanggup mengambil keputusan serta inisiatif dalam mengatasi masalah yang dihadapi, mempunyai kepercayaan diri untuk mengerjakan tugas-tugasnya, serta bertanggung jawab terhadap apa yang dilakukannya,(Prihatini et al., 2019). Hal ini sejalan dengan pendapat (Egok, 2016) yang mengemukakan bahwa siswa yang mempunyai kemandirian tinggi akan tumbuh rasa percaya diri yang tinggi pula.

Hal ini sejalan dengan penelitian Zengin (2012) yang menunjukkan 
DOI: https://doi.org/10.24127/ajpm.v9i2.2758

bahwa pembelajaran trigonometri berbantuan software Geogebra lebih efektif. Pemanfaatan program geogebra memberikan beberapa kelebihan, diantaranya: a) lukisan geometri dihasilkan lebih cepat dan teliti, 2) terdapat fasilitas animasi dan gerakan- gerakan manipulasi, dan 3) dimanfaatkan mahasiswa sebagai bahan evaluasi untuk mengecek kembali lukisan yang mahasiswa buat. Selanjutnya tingkat signifikansi dapat dilihat pada Tabel 5.

Tabel 5. Hasil uji ANOVA.

\begin{tabular}{cccccc}
\hline Model & Sum of Squares & $\boldsymbol{d} \boldsymbol{f}$ & Mean Square & $\boldsymbol{F}$ & Sig. \\
\hline Regression & 206.65 & 1 & 206.65 & 6.57 & $.014^{\mathrm{b}}$ \\
Residual & 1194.5 & 38 & 31.434 & & \\
Total & 1401.2 & 39 & & & \\
\hline
\end{tabular}

Berdasarkan Tabel 5 diperoleh bahwa nilai signifikansi sebesar 0,014. Nilai ini lebih kecil dari kriteria signifikan 0,05, dengan demikian model persamaan regresi berdasarkan data penelitian signifikan, yang berarti model regresi linier memenuhi kriteria

Tabel 6. Tabel koefisien persamaan regresi. linieritas. Sehingga dapat disimpulkan model regresi dapat dipakai untuk memprediksi variable kemandirian belajar. Koefisien pada model persamaan regresi dapat dilihat pada Tabel 6.

\begin{tabular}{rrrrrrr}
\hline \multirow{2}{*}{ Model } & \multicolumn{2}{c}{$\begin{array}{c}\text { Unstandardized } \\
\text { Coefficients }\end{array}$} & $\begin{array}{c}\text { Standardized } \\
\text { Coefficients }\end{array}$ & \multirow{2}{*}{$\boldsymbol{t}$} & \multirow{2}{*}{ Sig. } \\
\cline { 2 - 4 } & \multicolumn{1}{c}{$\boldsymbol{B}$} & \multicolumn{1}{c}{ Std. Error } & \multicolumn{1}{c}{ Beta } & & & \\
\hline (Constant $)$ & 60.121 & 10.98 & & 5.476 & .000 \\
Kemandirian & .387 & .151 & .384 & 2.564 & .014 \\
\hline
\end{tabular}

Berdasarkan Tabel 6 diperoleh model persamaan regresi sebagai berikut:

$$
Y=60.121+0.387 X
$$

dengan $Y$ adalah kemampuan berpikir kritis dan $X$ adalah kemandirian belajar. Dapat dilihat bahwa kemandirian belajar memiliki pengaruh positif terhadap kemampuan berpikir kritis mahasiswa. Hal ini dapat diartikan sebagai berikut; (a) apabila variabel lain bernilai konstan, maka nilai kemampuan berpikir kritis akan berubah sebesar nilai konstanta, sebesar 60.121, dan (b) apabila variabel lain bernilai konstan, maka nilai kemampuan berpikir kritis akan berubah sebesar 0.387 setiap satu satuan nilai kemandirian belajar.

Hasil di atas menunjukkan faktor kemampuan berpikir kritis dan faktor kemadirian belajar juga diduga mempunyai pengaruh yang cukup penting dalam pencapaian hasil belajar siswa. Hal ini disebabkan Kemandirian belajar merupakan suatu usaha yang dilakukan untuk melakukan aktivitas belajar dengan cara mandiri atas dasar motivasinya sendiri untuk menguasai suatu materi tertentu sehingga bisa 
dipakai untuk memecahkan masalah yang sedang dihadapi.

Hal ini sejalan dengan hasil penelitian (Prihatini et al., 2019) yang menemukan bahwa antara kemandirian belajar siswa dan berpikir kritis matematis terdapat hubungan positif. Hal ini juga didukung dengan hasil penelitian (Purnomo, 2017) yang menemukan bahwa terdapat pengaruh kemandirian belajar yang signifikan terhadap prestasi belajar matematika.

Hasil penelitian tersebut disebabkan karena kemandirian belajar siswa memberikan konstribusi yang cukup signifikan terhadap hasil belajar matematika, dimana kemandirian belajar yang positif akan membuat siswa proaktif dalam aktivitas belajarnya dengan cara mandiri atas dasar motivasinya sendiri dan tidak tergantung pada orang lain. Sebaliknya jika kemandirian belajar siswa rendah, maka siswa tidak akan proaktif dalam aktivitas belajarnya dan cenderung akan belajar saat mendapat perintah saja.

Hal ini didukung oleh penelitian sebelumnya yang dilakukan oleh (Kurniati, 2018), yang menyatakan bahwa siswa dapat mengeksplor pengetahuannya melalui Geogebra. Siswa yang dapat mengeksplor pengetahuannya akan mempunyai ilmu yang lebih luas. Penelitian yang menerapkan penggunakan Geogebra juga dilakukan oleh (Asngari, 2015) yang menyarankan bahwa program Geogebra dapat dimanfaatkan sebagai media pembelajaran matematika untuk memvisualisasikan konsep matematis serta sebagai alat bantu untuk mengkonstruksi konsep matematis.

Disamping itu, (Ekawati \& Mathematic, 2016) menyatakan bahwa Geogebra dapat digunakan sebagai media pembelajaran, alat bantu membuat bahan ajar, dan menyelesaikan soal matematika. Siswa dapat membuat konstruksi permasalahan matematika sendiri dan memecahkannya menggunakan Goegebra. Geogebra membuat matematika menjadi lebih interaktif dan menarik.

\section{KESIMPULAN DAN SARAN}

Penelitian ini dapat disimpulkan bahwa ada hubungan antara kemandirian belajar mahasiswa mahasiswa program studi pendidikan matematika Universitas Negeri Padang terhadap kemampuan berpikir kritis mahasiswa. Hasil tersebut dilihat bahwa nilai korelasi Pearson sebesar 0,412 menunjukkan kekuatan hubungan antara kemandirian belajar mahasiswa dengan kemampuan berpikir kritis.

Model regresi dapat dipakai untuk memprediksi variabel kemandirian belajar. Hal ini ditunjukkan oleh nilai signifikansi sebesar 0,014. Nilai ini lebih kecil dari kriteria signifikan 0,05, dengan demikian model persamaan regresi berdasarkan data penelitian signifikan. Sehingga dapat disimpulkan bahwa antara kemandirian belajar mahasiswa dengan kemampuan berpikir kritis memiliki hubungan yang positif.

Berhubungan dengan hasil kajian artikel yang didapat tentang adanya hubungan antara antara kemandirian belajar mahasiswa dengan kemampuan berpikir kritis mahasiswa, maka penulis menyusun beberapa saran yaitu; (1) perlu disadari bahwa tidak terdapat media yang paling baik atau paling tepat untuk semua topik pembelajaran matematika. Sehingga perlu diujicobakan software-software lain yang mendukung keterampilan mahasiswa dalam pembelajaran matematika khususnya geometri, (2) untuk mencapai efektivitas pembelajaran, penggunaan software ini 
perlu dikombinasikan dengan media pembelajaran lainnya, dan (3) dosen perlu juga mempertimbangkan kapan saat paling sesuai atau tepat dalam memanfaatkan program Geogebra.

\section{DAFTAR PUSTAKA}

Asngari, D. R. (2015). Penggunaan Geogebra dalam Pembelajaran Geometri. Seminar Nasional Matematika Dan Pendidikan Matematika UNY 2015, 299-302.

Batubara, I. H. (2019). Peningkatan Kemampuan Berpikir Kritis Mahasiswa Melalui Metode Penemuan Terbimbing Berbantuan Software Geogebra Pada Mata Kuliah Kalkulus Peubah Banyak Di Fkip Umsu. MES: Journal of Mathematics Education and Science, 4(2), 152-159. https://doi.org/10.30743/mes.v4i2. 1291

Cullinane, A. (2009). Bloom's Taxonomy and its Use in Classroom... (PDF Download Available). 1(October), 20092010.

https://www.researchgate.net/publi cation/283328372_Bloom's_Taxon omy_and_its_Use_in_Classroom_ Assessment

Dunne, G. (2015). Beyond critical thinking to critical being: Criticality in higher education and life. International Journal of Educational Research, 71, 86-99. https://doi.org/10.1016/j.ijer.2015. 03.003

Egok. (2016). Kemampuan Berpikir Kritis dan Kemandirian Belajar dengan Hasil Belajar Matematika. Journal of Chemical Information and Modeling, 53(9), 1689-1699. https://doi.org/10.1017/CBO97811 07415324.004
Ekawati, A., \& Mathematic, M. (2016). Penggunaan Software Geogebra Dan Microsoft. 2(3).

Eliserio, D. (2012). Self-Regulated Learning and Mathematics Achievement in a Fourth Grade Classroom Self-Regulated Learning and Mathematics Achievement in a Fourth Grade.

Hendryawan, S., Yusuf, Y., \& Wachyar, T. Y. (2017). Analisis Kemampuan Berfikir Kritis Matematis Siswa SMP Tingkat Rendah Pada Pembelajaran Berbasis Masalah dengan Green's Motivational Strategies. Aksioma, 8(2), 50. https://doi.org/10.26877/aks.v8i2.1 744

Kurniati, L. dkk. (2018). The Influence of Self Regulated Learning to Mathematics Critical Thinking Ability on 3D-Shapes Geometry Learning using Geogebra. JIPM (Jurnal Ilmiah Pendidikan Matematika), $\quad 7(1), \quad 40$. https://doi.org/10.25273/jipm.v7i1. 2965

Mardiana, S., \& Qohar, A. (2017). Pengembangan Media Interaktif Berbasis Penemuan Terbimbing “TRANSGEO. " 6(1), 20-27.

Nduru, R. E., Situmorang, M., \& Tarigan, G. (2014). Analisa Faktor-Faktor Yang Mempengaruhi Hasil Produksi Padi Di Deli Serdang. Saintia Matematika, 2(1), 71-83.

Prihatini, D., Hidayat, W., \& Rohaeti, E. E. (2019). Hubungan antara kemampuan berpikir kritis matematis dan kemandirian belajar siswa sma cimahi. 02(01), 167-173. 
DOI: https://doi.org/10.24127/ajpm.v9i2.2758

Purnomo, Y. (2017). Pengaruh Sikap Siswa pada Pelajaran Matematika dan Kemandirian Belajar Siswa terhadap Prestasi Belajar Matematika. JKPM (Jurnal Kajian Pendidikan Matematika), 2(1), 93. https://doi.org/10.30998/jkpm.v2i1 .1897

Rohendi, D. (2012). Developing ELearning Based on Animation Content for Improving Mathematical Connection Abilities in High School Students. International Journal of Computer Science Issues, 9(4), 1-5.

Saputra, E. dkk. (2019). Pemanfaatan Software Geogebra Pada Matakuliah Matematika Untuk Meningkatkan Kemandirian Belajar Mahasiswa Prodi Arsitektur Universitas Malikussaleh. Journal of Chemical Information and Modeling, 6(2), 212-217.

https://doi.org/10.1017/CBO97811 07415324.004

Sumarmo, U., Hidayat, W., Zukarnaen, R., Hamidah, M., \& Sariningsih, R. (2012). KEMAMPUAN DAN DISPOSISI BERPIKIR LOGIS, KRITIS, DAN KREATIF MATEMATIK (Eksperimen terhadap Siswa SMA Menggunakan Pembelajaran Berbasis Masalah dan Strategi Think-Talk-Write). Jurnal Pengajaran Matematika Dan Ilmu Pengetahuan Alam, 17(1), 17. https://doi.org/10.18269/jpmipa.v1 $7 \mathrm{i} 1.228$

Supriadi, N. (2015). Pembelajaran Geometri Berbasis Geogebra Sebagai Upaya Meningkatkan Kemampuan Komunikasi Matematis. Al-Jabar: Jurnal Pendidikan Matematika, 6(2), 99109. http://ejournal.upi.edu/index.php/jp manper/article/view/00000\%0AIm pak

Van-Oers, B. (2010). Emergent mathematical thinking in the context of play. Educational Studies in Mathematics, 74(1), 2337. https://doi.org/10.1007/s10649009-9225-x 